\title{
The Political Tolerance and the Youth Perceived Participation in Malaysia
}

\author{
Mohd Azmir Mohd Nizah
}

Centre for Core Studies, Universiti Sains Islam, Malaysia

\begin{abstract}
Abstarct
This article was initiated to recognize the level of political tolerance in a multiethnic society of Malaysia, with a specific orientation to the district of Kuala Langat, Selangor, Malaysia. It also aimed at identifying factors that stimulus political tolerance in the area involved. In a survey of political tolerance of 200 respondents, this study begs the question of the relationship of political tolerance and youth participation in political activities. It is imperative to study due to the demographic distinctiveness and generality power of expanse for forecasting near future of political and voting tendencies in Selangor. The findings reveal that the youth of Kuala Langat district can be categorized as medium good of political tolerance practitioners, as democratic values and civic participation are more significant than the issue of party politics and ethnicity. It is substantial where moderation has become gradually Malaysia national plan in managing plural society. Results and discussions are further discussed.
\end{abstract}

Keywords: Voting, Tolerance, Civic Participation, Democratic Values

\section{Introduction}

Since Malaysia independence, national integration has been fundamental for Malaysia success and growth and even become one of the main agenda for Vision 2020 (Mahathir, 1991). Due to multi-ethnicity, multicultural and multi-religiosity of Malaysian citizens, which subsequently required tolerance value and behaviour, thus become the key factor for economic, political and social stability (Banton, 1985; Jayum A. Jawan, 1996; Mohd Nizah, Ahmad, Jawan, Ku Samsu, \& Gill, 2017). Tolerance also importance for democratic state (Arwine \& Mayer, 2012; Inglehart \& Welzel, 2005; MarquartPyatt \& Paxton, 2006; Oskarsson \& Widmalm, 2016). However, Malaysia political concerned is much more on ethnicity (Jayum A. Jawan \& Mohammad Agus, 2008; Mohd Azmir Mohd Nizah, 2015), which becomes a huge task to maintains its harmony. Apart from it, scholars agreed that active participation in political activities may breed tolerance behavior (Chzhen, 2013; McClosky \& Brill, 1983; Togeby, 2004). The divergence accounts on tolerance and participation become the main concern of this study. In doing so, a comprehensive study on youth in Selangor tolerance attitude and behaviour may explain further such phenomenon. It also focuses on the effect of tolerance behavior towards voting behavior among youth in Selangor.

\section{Literature}

Empirically, the literature that discusses tolerance only began in 1950 in the United States that explore issues of civil rights of citizens, immigration immigrants in Europe and the existence of a new nation-state entities but have a plural character. While local tolerance study highlights many focus on the factors contributing to national reconciliation, for instance through the use of media (Ezhar Tamam, Tien, Fazilah Idris, \& Azimi Hamzah, 2006); or personality through youth (Fazilah Idris \& Nur Riza Suradi, 2010) ; or through education and ethnic identity (Brown, 2005a; Mohd Azmir Mohd Nizah, 2015; Mohd Azmir Mohd Nizah \& Paimah, 2011; Nazri Muslim \& Mansor Mohd Noor, 2014), or through ethnic polarization (Balasubramaniam, 2006; Chin Yee Mun, Lee Yok Fee, Jayum Jawan, \& Sarjit Singh Darshan Singh, 2014), or even in the context of perception, contact, conflict and differences of opinion (Brown, 2005b; Hari Singh, 2010; Ming, Azhar, Hazri, \& Mulakala, 2012; Nazri Muslim \& Mansor Mohd Noor, 2014). In addition, there are many studies done by local scholars in the matter of patriotism (Ahmad Sabri, Abdul Aziz, Shafie, \& Nordin, 2014; Aznan Bakar, 2010; Ku Hasnita Ku Samsu, 2009 ) with various conclusion, with the recent findings showed a concerns of patriotism among youth (Institut Penyelidikan Pembangunan Belia Malaysia, 2011). 
Based on the above literature, it clearly shows that there are still shortcomings in the studies of tolerance, especially the youth in Malaysia, where almost all did not discuss the major issues of tolerance of the people. The question as to how the national unity could be improved if the tolerance among ethnic and political space is not assessed in advance? Or how to shape the attitudes of youth patriotism if the ethnic and political tolerance measures does not exist?

Public support for the principle of democracy is very important, as emphasized by Gibson, Duch, \& Tedin (1992) which defines tolerance as the character of someone who believes in individual freedom for political tolerance and supports democratic institutions and democratic processes. This definition thus becomes a universal measure of individual tolerance. But this definition is also paves to the question of which this tolerant belief affect behaviour tolerant and whether it can be measured through voting behaviour? But tolerance is not only measured by its own domain but also from form of participation, including voting behaviour. Admittedly, studies voting behaviour is the fastest growing sector which in line with the rapid democratic system, the media and the civil rights movement of individuals, but in Malaysia, analyses related to voting behaviour are still bound by the sociologists 'ethnic census'. So, this study is trying to push boundaries with voting behaviour models based on tolerance youths in Kuala Langat, Selangor.

There are much more lacks studies that lead to the question of the ultimate behaviour of tolerance for the conduct of the political and ethnic (Finkel, Sigelman, \& Humphries, 1999), but most of the literature that exists is discuss the tolerance of the people against the prejudice (Gibson, 2006; Sullivan, Piereson, \& Marcus, 1982; Weldon, 2006); tolerance towards immigrants (Cote \& Erickson, 2009); or against religious differences (Ahmad Tarmizi, Sarjit Singh Gill, Razaleigh, \& Puvaneswaran Kunasekaran, 2013); nor on the education system (Janmaat \& Mons, 2011). There is virtually no literature discussing political tolerance and discusses its relationship to voting behaviour.

Mutz (2005) found that tolerance will increase due to a variety of political views but have a negative impact on political participation, and the impact of urban influence is very significant. The result of the impact of urban influence is supported in a recent study by Widmalm \& Oskarsson (2013). While Arwine \& Mayer (2012) found a high tolerance can lead to ethnic conflict diminished. There exists a logical contradiction in the views of both these masters, which proposed this study to try to find a meeting point and a tolerance and equality in voting behaviour. So, this study will attempt to answer the question of level of political tolerance among youths in Kuala Langat, Selangor. Reviewed literature showed almost no studies made in understanding the political tolerance of youth. Data of Malaysian Youth Index (Institut Penyelidikan Pembangunan Belia Malaysia, 2011) related to patriotism, unity and political participation is used for questions analyses. The question of whether the affects the tolerance of youth voting behaviour, especially when it comes to urban voters which make $71 \%$ of the whole society (Department of Statistics Malaysia, 2010) will be explored.

The study attempt to measure political tolerance youths in Kuala Langat, which is expected to describe the situation of tolerance people of Selangor and Malaysia as a whole. This is very significant because Kuala Langat which has 7 districts with the population by an ethnic population that reflects the composition of society. In addition, this study will also try to determine the effects of political and ethnic tolerance of youth voting behaviour.

\section{Methodology}

This study will adopt the design of the study "explanatory" with a backdrop of quantitative research methods section. Set interviews (survey) will be developed by the researchers divided into three elements, namely 1) demographic information 2) political tolerance and 3) the conduct of the voting. Mechanical engineering survey is the most widely used by scholars and considered standard procedure in studies of tolerance (Mather \& Tranby, 2014).

Items are in the form of closed questions (closed-ended) with the Likert scale from 1 (strongly disagree) to 10 (strongly agree). The sample covers the entire seven districts in Kuala Langat, Selangor and is based on surveys conducted by the Department of Statistics Malaysia (2013), which includes 58.534 youths aged 20-30 years were randomly selected through multi-stage cluster sampling technique (multi-stage cluster sampling) include all ethnic groups. The respondents were 384 people is adequate for a population of more than 100,000 thousand people (Krejcie \& Morgan, 1970), while this study is trying to get as many as 200 respondents who meet the minimum requirements of the power of the sample. The table below is a summary of the number of respondents by ethnicity and sub-district accordingly. 


\begin{tabular}{|l|l|l|l|l|}
\hline ETHNIC & MALAY & CHINESE & INDIAN & OTHERS \\
\hline SUB-DISTRICT & & & & \\
\hline Bandar & 16 & 4 & 2 & 1 \\
\hline Batu & 10 & 7 & 2 & 1 \\
\hline Jugra & 12 & 4 & 2 & 2 \\
\hline Kelanang & 10 & 4 & 5 & 1 \\
\hline Morib & 12 & 4 & 5 & 2 \\
\hline Tg. Dua Belas & 22 & 12 & 8 & 1 \\
\hline Telok Panglima Garang & 31 & 10 & 8 & 2 \\
\hline TOTAL & 113 & 45 & 32 & 10 \\
\hline TOTAL & 200 & & \\
\hline
\end{tabular}

Descriptive data will be analyzed using IBM software Statistical Program for Social Sciences (SPSS) version 20. The mean value, the frequency and the gap (Coakes \& Ong, 2011) will be analyzed for a patent and data patterns. The data will then be analyzed by Structural Equation Modeling (SEM) by using IBM SPSS Amos 20 version in identifying, estimating and evaluating the model to show the relationship between variables. The model is expected to be a reference for future studies in the context of political-ethnic tolerance among the youth in particular and the public generally.

\section{Result \& Discussion}

After three months of data collection progress, 250 survey form were distributed, while after deducing due to missing and incomplete forms, only 201 were made for analysis stage. Descriptively, from 201 respondents, 84.8 per cent of the respondents are eligible to be considered as youth borrowing from the definition set by Institut Penyelidikan Pembangunan Belia Malaysia (2011). While in term of gender difference, 70 percent of respondents are male while 30 percent were female. In term of ethnicity, 73 percent were Malays, 9.4 were Chinese, 5.4 were Indian, and the balance of 12 per cent were others including Sabah and Sarawak and Orang Asli. While in term of education, most of respondents are Sijil Pelajaran Malaysia (SPM) holders with 54.3 percent, 17 percent are Certificate holders and 18,6 percent were diploma level of education. Interestingly, 94.9 percent of the respondents are supporter for political party while only 5 percent were not. Therefore, based on the demographic identification of respondents, the measurement for political tolerance level in Kuala Langat youth is emminent.

There are 15 items being used to measure political tolerance. Based on alpha, the score is $.937(\partial=>.8)$, which can be understand that all items are reliable and valid for the measurement. Table 1 below manifest the validity and reliability of items used.

\begin{tabular}{|l|l|l|}
\hline Cronbach's Alpha & Cronbach's Alpha Based on Standardized Items & N of Items \\
\hline .945 & .945 & 15 \\
\hline
\end{tabular}

Table 1 Items Validity and Reliability

Because all items used are statitiscally reliable and valid for the measurement based on on Cronbach's Alpha, then determinant of mean score for items is necessary to determine the level of political tolerance among youth in Kuala Langat. Mean score for political tolerance constructs was 6.08. This score can be interpret as medium- good of political tolerance practices amongst ethnic in Kuala Langat as suggested by scale developed by Mohd Azmir Mohd Nizah \& Ku Hasnita Ku Samsu (2015).

\begin{tabular}{|l|l|l|}
\hline Mean & N & Std. Deviation \\
\hline 6.0791 & 190 & 1.38698 \\
\hline
\end{tabular}

Table 2 Mean Scale for Political Tolerance

Table 2 shows that respondents achieved medium-good level of ethnic tolerance. The scores are dependent on ethnicity, constituency, gender and academic qualification. Statistical analysis presented that there was a significant difference based on ethnicity. 


\begin{tabular}{|l|l|l|l|l|l|}
\hline & Sum of Squares & df & Mean Square & F & Sig. \\
\hline Between Groups & 34.899 & 67 & .521 & 1.682 & .007 \\
\hline Within Groups & 37.780 & 122 & .310 & & \\
\hline Total & 72.679 & 189 & & & \\
\hline
\end{tabular}

Table 3 Group Difference

Table 3 shows the result of the difference where there was a statistically significant difference between groups as determined by one-way ANOVA $(F 67,122)=1.682, p<.05$.

\begin{tabular}{|l|l|l|l|}
\hline Ethnic & Mean & N & Std. Deviation \\
\hline Malay & 6.1374 & 147 & 1.44486 \\
\hline Chinese & 6.0210 & 27 & 1.19944 \\
\hline Indian & 5.6411 & 16 & 1.08705 \\
\hline Total & 6.0791 & 190 & 1.38698 \\
\hline
\end{tabular}

Table 4 Political Tolerance Level

Table 4 as the above showed that based on ethnicity, the Malays youth are more politically tolerated, but does not differ significantly with the Chinese and the Indian in Kuala Langat. Overall, based on the objective set previously, this study found that the level of political tolerance among youth in Kuala Langat at medium good level. This can be assessed through local youth activities including various community based awareness campaign such as Food for the Needy, Banting Menjerit, Jugra Hiking, Schoolings Equipment Assistance, and some other political discourse that involved the youth directly. Leadership qualities also plays important roles in mediating the effect of political tolerance through youth participation. It must be noted that youth in Kuala Langat are very much concerned of their well-being rather than on sole interest in party politics.

\section{Conclusion}

It can be concluded that the youth in Kuala Langat can be categorised as medium-good of political tolerance practitioners, as civic and democratic participation are more important than the issue of political parties and ethnicity. Interestingly, the youth does not consider ethnic identity as obstacles but rather their self being is much more important. Therefore, more studies on are needed in measuring and understanding political tolerance. Most importantly, when it involves gaining political support and harnessing votes in electoral process, definitely political tolerance becomes one of the indicators, at least it prevails in sub-urban society. Governing parties should chart new strategies for upcoming election. This is the way forward.

\section{Acknowledgment}

This material is based upon work supported by the Universiti Sains Islam Malaysia Short Term Grant under grant No: PPP/USG-0216/FKP/30/17816

\section{References}

[1] Ahmad Sabri, A. Z. S., Abdul Aziz, A. R., Shafie, S., \& Nordin, M. N. A. (2014, March 3). Kajian terhadap tahap patriotisme dalam kalangan belia Perak. Universiti Utara Malaysia. Retrieved from http://repo.uum.edu.my/11665/1/Ah Za.pdf

[2] Ahmad Tarmizi, . Talib, Sarjit Singh Gill, ., Razaleigh, . Muhamat Kawangit, \& Puvaneswaran Kunasekaran, .. (2013). Religious Tolerance: The Key between One ASEAN One Community. Life Science Journal, 10(4), 13821385.

[3] Arwine, A., \& Mayer, L. (2012). The Impact of Tolerance on Political Behavior (2012 Annual Meeting). Portland, Oregon.

[4] Aznan Bakar, . (2010, December 27). Belia dan patriotisme. Utusan Online. Retrieved from $\mathrm{http}: / / w w 1 . u t u s a n . c o m . m y / u t u s a n / i n f o . a s p ? y=2010 \& d t=1227 \&$ pub=Utusan_Malaysia\&sec=Rencana\&pg=re_0 
2.htm

[5] Balasubramaniam, V. (2006). Strengthening ethnic identity consciousness and the role of tactical voting in multiracial Malaysia. Asian Ethnicity, 7(1), 75-88. http://doi.org/10.1080/14631360500498536

[6] Banton, M. (1985). Promoting Racial Harmony (1st ed.). Cambridge, United Kingdom: Cambridge University Press.

[7] Brown, G. (2005a). Making ethnic citizens : The politics and practice of education in Malaysia October 2005, (23).

[8] Brown, G. (2005b). Playing the (non)ethnic card: The electoral system and ethnic voting patterns in Malaysia. Ethnopolitics, 4(4), 429-445. http://doi.org/10.1080/17449050500348675

[9] Chin Yee Mun, ., Lee Yok Fee, ., Jayum Jawan, ., \& Sarjit Singh Darshan Singh, .. (2014). From Individual Choice to Collective Actions: Ethnic Consciousness in Malaysia Reconsidered. Ethnic and Racial Studies, (January), 1-15. http://doi.org/10.1080/01419870.2013.863958

[10] Chzhen, Y. (2013). Education and Democratisation: Tolerance of Diversity, Political Engagement, and Understanding of Democracy.

[11] Cote, R. R., \& Erickson, B. H. (2009). Untangling the Roots of Tolerance: How Forms of Social Capital Shape Attitudes Toward Ethnic Minorities and Immigrants. American Behavioral Scientist, 52(12), 1664-1689. http://doi.org/10.1177/0002764209331532

[12] Department of Statistics Malaysia. (2010). Population Distribution and Basic Demographic Characteristics. Putrajaya.

[13] Department of Statistics Malaysia. (2013). GDP by State. Putrajaya.

[14] Ezhar Tamam, .., Tien, W. Y. M., Fazilah Idris, ., \& Azimi Hamzah, . (2006). News Media Socialization and Ethnic Tolerance. 15th AMIC Annual Conference, (July), 1-10.

[15] Fazilah Idris, ., \& Nur Riza Suradi, . (2010). The Influence of Youth Personality towards Racial Integration. The International Journal of Learning, 16(12). Retrieved from http://ijl.cgpublisher.com/product/pub.30/prod.2572

[16] Finkel, S. E., Sigelman, L., \& Humphries, S. (1999). Democratic Values and Political Tolerance. In J. P. Robinson, P. R. Shaver, \& L. S. Wrightsman (Eds.), Measures of Political Attitudes (Vol. 2, pp. 203-296). San Diego, California: Academic Press.

[17] Gibson, J. L. (2006). Do Strong Group Identities Fuel Intolerance? Evidence From the South African Case. Political Psychology, 27(5), 665-705. http://doi.org/10.1111/j.1467-9221.2006.00528.x

[18] Gibson, J. L., Duch, R. M., \& Tedin, K. L. (1992). Democratic Values and the Transformation of the Soviet Union. The Journal of Politics, 54(2), 329-371. http://doi.org/10.2307/2132030

[19] Hari Singh. (2010). Ethnic Conflict in Malaysia Revisited. Commonwealth \& Comparative Politics, 39(1), 42-65. http://doi.org/10.1080/713999532

[20] Inglehart, R., \& Welzel, C. (2005). Modernization, cultural change, and democracy : the human development sequence. Cambridge University Press.

[21] Institut Penyelidikan Pembangunan Belia Malaysia. (2011). Indeks Belia Malaysia 2011. Putrajaya, Malaysia.

[22] Janmaat, J. G., \& Mons, N. (2011). Promoting Ethnic Tolerance and Patriotism : The Role of Education System Characteristics. Comparative Education Review, 55(1), 56-81. http://doi.org/10.1086/657105

[23] Jayum A. Jawan. (1996). Conflict Resolution Through Consensus Building : Experiences from the Dayak Than Community of Sarawak, East Malaysia. Pertanika Journal of Social Sciences \& Humanities, 4(2), 121-127.

[24] Jayum A. Jawan, \& Mohammad Agus, Y. (2008). The 2008 General Elections: Implications for Ethnic Relations in Malaysia. In Globalising Religions and Cultures in the Asia Pacific (pp. 3-40). Adelaide: The University of Adelaide.

[25] Krejcie, R. V, \& Morgan, D. W. (1970). Determining Sample Size For Research Activities. Educational and Psychological Measurement, 38, 607-610.

[26] Ku Hasnita Ku Samsu, M. H. M. N. (2009). Patriotism among non-Malay Students in Public Higher Education Institution , Around Klang Valley Semangat Patriotisme dalam Kalangan Mahasiswa Bukan Melayu di Institusi Pengajian Tinggi , Sekitar Lembah Kelang. Akademia, 75, 85-100.

[27] Mahathir, .. (1991). The Way Forward-Vision 2020. Retrieved from http://www.wawasan2020.com/vision/p2.html

[28] Marquart-Pyatt, S., \& Paxton, P. (2006). In Principle and in Practice: Learning Political Tolerance in Eastern and Western Europe. Political Behavior, 29(1), 89-113. http://doi.org/10.1007/s11109-006-9017-2 
[29] McClosky, H., \& Brill, A. (1983). Dimension of Tolerance: What Americans Believe About Civil Liberties. New York: Russel Sage Foundation.

[30] Ming, L. L., Azhar, N. A., Hazri, H., \& Mulakala, A. (2012). The Youth Factor: 2012 Survey of Malaysian Youth Opinion. Kuala Lumpur.

[31] Mohd Azmir Mohd Nizah, .. (2015). On Malaysia's Ethnic Tolerance: A Study of Two Cities. Research Journal of Applied Sciences, 10(8), 294-297. http://doi.org/10.3923/rjasci.2015.294.297

[32] Mohd Azmir Mohd Nizah, .., \& Ku Hasnita Ku Samsu, .. (2015). Political Tolerance in Multi Ethnic Society: An Early Findings in Johor Bahru Parliamentary, Malaysia. In Seminar On Government And Civilisation II (SOGOC II) (pp. 450-462). Serdang, Selangor, Selangor: Universiti Putra Malaysia.

[33] Mohd Azmir Mohd Nizah, .., \& Paimah, A. (2011). Magnitud Toleransi dan Urbanisasi dalam Kalangan Pelajar Pelbagai Etnik: Kajian Perbandingan di Kuala Lumpur dan Kuantan. In Persidangan Kebangsaan Perpaduan Nasional 2011. Kuala Lumpur.

[34] Mohd Nizah, M. A., Ahmad, H., Jawan, J., Ku Samsu, K. H., \& Gill, S. S. (2017). Ethnic Tolerance in Multiethnic Society: The Case of Pulau Pinang. In The European Proceedings of Social \& Behavioural Science (pp. 6674). London: Future Academy. http://doi.org/10.15405/epsbs.2017.02.6

[35] Mutz, D. C. (2005). Hearing the Other Side: Deliberative versus Participatory Democracy. Cambridge: Cambridge University Press.

[36] Nazri Muslim, ., \& Mansor Mohd Noor, . (2014). Ethnic Tolerance Among Students of Public Higher Learning Institutions in Malaysia. World Applied Sciences Journal, 29(3), 388-401. http://doi.org/10.5829/idosi.wasj.2014.29.03.992

[37] Oskarsson, S., \& Widmalm, S. (2016). Personality and political tolerance: Evidence from India and Pakistan. Political Studies, 64(1), 235-254. http://doi.org/10.1111/1467-9248.12169

[38] Sullivan, J. L., Piereson, James, \& Marcus, George E. (1982). Political Tolerance \& American Democracy (Paperback). Chicago: The University of Chicago Press.

[39] Togeby, L. (2004). It depends... how organisational participation affects political participation and social trust among second-generation immigrants in Denmark. Journal of Ethnic and Migration Studies, 30(3), 509-528. http://doi.org/10.1080/13691830410001682061

[40] Weldon, S. A. (2006). The Institutional Context of Tolerance for Ethnic Minorities: A Comparative, Multilevel Analysis of Western Europe. American Journal of Political Science, 50(2), 331-349. http://doi.org/DOI 10.1111/j.1540-5907.2006.00187.x

[41] Widmalm, S., \& Oskarsson, S. (2013). Political Tolerance in India Descriptions and Explanations from the Heartland. Asian Survey, 53(3), 533-558. 